\title{
PERILAKU HIDUP BERSIH DAN SEHAT TATANAN TEMPAT - TEMPAT UMUM \\ (Studi Kasus Pedagang Makanan Minuman di Terminal Purabaya Surabaya Tahun 2014) Junanda Eka Prisandoyo, Ngadino, Didik Sugeng Purwanto
}

\begin{abstract}
The so called Public Places are places where many people gather and perform activities incidentally or continuously. Activities in public places are vulnerable to threats of disease transmission, either directly or indirectly. To maintain and improve health conditions, the PHBS way of life needs to be practised. The purpose of the study was to determine the practice of the PHBS principles in public places especially among the food stalls.

Based on the method of data analysis this was considered a descriptive study with cross sectional approach. Data was gathered through questionnaires, check lists and observations. The number of samples in this study was 55 owners of food vendors. The data obtained were subjected to subsequent descriptive analysis.

Results of the study with regard to knowledge level showed that $63,6 \%$ of respondents have sufficient level of knowledge. attitudes the study showed that $63,6 \%$ of respondents were considered adequate. While in terms of the action the study showed that $83,6 \%$ of respondents can in the IIIrd classification, where among the 10 indicators there are only $7-9$ qualified indicators that met the requirements, due to the absence of good garbage bins and lack of hand washing facilities.

The study suggested that promotional programs need to be intensified to improve the PHBS parctices in public places. Managers of the bus terminal need to provide food vendors with proper hand washing facilities.
\end{abstract}

Keywords : food stalls, PHBS practices; public places; bus terminal

\section{PENDAHULUAN}

Mengingat bahwa banyaknya kegiatan atau aktivitas yang terjadi pada tempat - tempat umum sehingga meningkatkan hubungan atau kontak antar orang yang satu dengan orang yang lain dimana orang yang satu dengan orang yang lain kemungkinan tidak mengenal satu sama lainnya. Penularan penyakit bisa terjadi meskipun orang yang satu dengan orang yang lain tidak saling mengenal, asalkan ada agent yang menularkan penyakit dalam hal ini agentnya adalah orang yang sakit menularkan penyakit kepada orang yang sehat. Penularan penyakit secara kontak langsung baik berupa kita berdekatan dengan orang yang mengidap flu dan udara tercemar oleh virus yang keluar dari dalam tubuh orang lain melalui bersin dan batuk. Sedangkan kontak secara tidak langsung yaitu melalui sebuah perantara yaitu berupa benda - benda, alat - alat yang dipergunakan dalam melakukan kegiatan baik seperti kegiatan transaksi maupun kegiatan yang lain.

Hal pertama yang dilakukan dalam upaya memelihara dan meningkatkan kesehatan adalah memberikan pendidikan kesehatan. Pemberian pendidikan kesehatan yang baik diharapkan akan mempengaruhi perilaku seseorang untuk hidup sehat, sehingga pada akhirnya perilaku - perilaku hidup bersih dan sehat yang dilakukan terus menerus akan menjadikan suatu kebiasaan untuk hidup sehat. Dengan kata lain, perilaku hidup bersih dan sehat penting dilakukan untuk memelihara dan meningkatkan kualitas kesehatan seseorang. Perilaku hidup bersih dan sehat dapat kita laksanakan dimana saja, seperti : pada tatanan rumah tangga, tatanan pendidikan, tatanan tempat kerja maupun pada tatanan tempat tempat umum. Perilaku hidup bersih dan sehat pada tatanan tempat - tempat umum adalah upaya membudayakan perilaku hidup bersih dan sehat masyarakat di tempat - tempat umum untuk mengenali masalah dan tingkat kesehatannya, serta mampu mengatasi, memelihara, meningkatkan dan melindungi kesehatannya sendiri. ( Dinkes Prov Jawa Timur, 2001: 4- 5 ).

Sebagai sarana penunjang transportasi dalam kota, lintas kota bahkan hingga lintas pulau, Terminal Purabaya sebagai terminal kelas 1 atau strata A merupakan tempat berkumpulnya banyak orang dari berbagai daerah sehingga akan ditemukan banyak perilaku orang berbeda - beda. Bukan hanya para pengunjung saja tetapi juga para pengelola terminal, para pedagang dan juga pemilik warung makan yang melakukan aktivitas secara insidentil maupun terus menerus. Dengan banyaknya kegiatan yang dilakukan dikhawatirkan terjadinya penularan penyakit. Untuk itu penting dilakukan upaya - upaya kesehatan, seperti program Sanitasi Tempat - Tempat Umum dan Perilaku Hidup Bersih dan Sehat. Oleh karena itu peneliti tertarik untuk melakukan penelitian di Terminal Purabaya dengan prioritas penerapan Perilaku Hidup Bersih dan Sehat pada warung makan. 
Tujuan dari penelitian ini adalah Mengetahui perilaku hidup bersih dan sehat tatanan tempattempat umum khususnya pedagang makanan minuman di Terminal Purabaya Surabaya.

\section{METODE PENELITIAN}

Ditinjau dari metodenya penelitian ini menggunakan metode penelitian survey, ditinjau dari analisis datanya makapenelitian ini merupakan penelitian survei deskriptif dan menurut pendekatannya penelitian ini termasuk "cross sectional '2012: 37). Dalam penelitian ini sampel adalah seluruh jumlah dari populasi yaitu sejumlah 55 warung makan yang ada diwilayah terminal purabaya. Hal ini dikarenakan jumlah populasi yang sedikit sehingga menurut peneliti tidak perlu dilakukan sampling.

Variabel terikat dalam penelitian ini adalah perilaku hidup bersih dan sehat sedangkan variabel bebas dalam penelitian ini adalah perilaku. Sub variabel dalam penelitian ini adalah pengetahuan, sikap dan tindakan.

Teknik pengumpulan data dalam penelitian ini menggunakan data primer yang didapatkan langsung dari lapangan yang merupakan hasil dari penyebaran Kuisioner, penyebaran Angket, Check List dan Observasi dan data sekunder yang diperoleh dari instansi terkait. Analisis data menggunakan analisis deskriptif pada data-data yang telah diperoleh.

\section{HASIL PENELITIAN DAN PEMBAHASAN Pengetahuan}

Tabel. 1

Distribusi Tingkat Pengetahuan Responden Tentang PHBS Tatanan Tempat-Tempat Umum (Warung Makan) di Wilayah Terminal Purabaya Surabaya

\begin{tabular}{|l|l|c|c|}
\hline No & $\begin{array}{l}\text { Tingkat } \\
\text { Pengetahuan }\end{array}$ & Jumlah & Persen (\%) \\
\hline 1. & Baik & 9 & 16,4 \\
\hline 2. & Cukup & 35 & 63,6 \\
\hline 3. & Kurang & 11 & 20,0 \\
\hline Total & 55 & 100,0 \\
\hline
\end{tabular}

Berdasarkan tabel tingkat pengetahuan di atas, di ketahui bahwa sebagian besar responden memiliki tingkat pengetahuan cukup dengan presentase sebesar $63,6 \%$ ( 35 responden ), sedangkan sebagian kecil lainnya memilikj tingkat pengetahuan baik dengan presentase sebesar $16,4 \%$ (9 responden). Berdasarkan data di atas menunjukkan bahwa sebagian besar responden memiliki tingkat pengetahuan yang cukup yaitu 35 responden $(63,6 \%)$. Setelah melakukan analisa, responden yang memiliki tingkat pendidikan SMP sebanyak 27, dari 27 responden tersebut yang memilikj tingkat pengetahuan terkait PHBS sebesar 23 responden.

\section{Sikap}

Tabel.2

Distribusi Sikap Responden Tentang PHBS Tatanan Tempat - Tempat Umum (Warung Makan) di Wilayah Terminal Purabaya Surabaya

\begin{tabular}{|l|l|c|c|}
\hline No & Sikap & Jumlah & Persen (\%) \\
\hline 1. & Baik & 6 & 10,9 \\
\hline 2. & Cukup & 35 & 63,6 \\
\hline 3. & Kurang & 14 & 25,5 \\
\hline Total & 55 & 100,0 \\
\hline
\end{tabular}

Berdasarkan tabel sikap di atas, di ketahui bahwa sebagian besar responden memiliki sikap cukup dengan presentase sebesar $63,6 \%$ ( 35 responden), sedangkan sebagian kecil lainnya memiliki sikap baik dengan presentase sebesar $10,9 \%$ ( 6 responden ). Dari hasil pengumpulan data meskipun sikap terhadap PHBS dinyatakan cukup belum tentu pemilik warung melakukan PHBS, hal ini sebagaimana dinyatakan oleh Newcomb dalam Notoatmodjo sikap seseorang tidak selalu diikuti dengan tindakan, karena sikap merupakan kesiapan atau kesediaan untuk bertindak atau dengan kata lain sikap merupakan faktor predisposisi perilaku. 


\section{Tindakan}

Tabel.3

Distribusi Tindakan Responden Tentang PHBS Tatanan Tempat - Tempat Umum ( Warung Makan ) di Wilayah Terminal Purabaya Surabaya

\begin{tabular}{|c|c|c|c|}
\hline No & Tindakan & Frekuensi & Persen ( \%) \\
\hline 1. & Klasifikasi I & 0 & 0 \\
\hline 2. & Klasifikasi II & 0 & 0 \\
\hline 3. & Klasifikasi III & 46 & 83,6 \\
\hline 4. & Klasifikasi IV & 9 & 16,4 \\
\hline & Total & 55 & 100,0 \\
\hline
\end{tabular}

Berdasarkan tabel tindakan di atas, menunjukan bahwa warung makan yang melaksanakan 10 indikator PHBS tatanan tempat - tempat umum ( klasifikasi IV ) yaitu sebesar 9 responden $(16,4 \%)$ sedangkan yang melaksanakan $7-9$ indikator ( klasifikasi III) yaitu sebesar 46 responden $(83,6 \%)$.

Dengan hasil tersebut menunjukan bahwa 83,6\% PHBS di Terminal Purabaya belum dilakukan secara optimal mengingat masih terdapat 2 indikator yang belum dilakukan yaitu ketidak tersedian tempat sampah dan tempat cuci tangan disebabkan karena meskipun pengetahuan cukup ( SMP dan SMA ) namun para responden belum memilikj sikap yang baik terhadap PHBS.

\section{Perilaku Hidup Bersih dan Sehat}

Penilaian Perilaku Hidup Bersih dan Sehat para pemilik warung yaitu dengan cara menyimpulkan analisa hasil perilaku yang dipengaruhi oleh 3 faktor yaitu: tingkat pengetahuan, sikap, dan tindakan, sehingga dari hasil penelitian menunjukan bahwa warung makan ber PHBS III ( 70,3\%) artinya PHBS di Terminal Purabaya masuk dalam kategori baik namun belum sangat baik. $\mathrm{Hal}$ ini disebabkan masih terdapat 2 indikator yang belum terpenuhi yaitu tersedianya tempat sampah dan tersedianya tempat cuci tangan.

Dari hasil wawancara diketahui bahwa pemilik tidak menyediakan tempat sampah karena tidak mengetahui bahwa tidak adanya tempat sampah yang memenuhi syarat dapat mengundang vektor penyakit yang akan menimbulkan gangguan kesehatan bagi manusia. $\mathrm{Hal}$ ini di maklumi mengingat pengetahuan PHBS mereka masih ada yang kurang $(20,0 \%)$, dan dari sisi sikap mereka juga menunjukkan kurangnya kepedulian terhadap PHBS ( $25,5 \%$ ).

\section{KESIMPULAN}

1. Tingkat pengetahuan tentang 10 indikator PHBS tatanan tempat - tempat umum, sebagian besar tingkat pengetahuan cukup sebesar 35 responden $(63,6 \%)$.

2. Sikap responden terhadap 10 indikator PHBS tatanan tempat - tempat umum sebagian besar memiliki sikap cukup sebesar 35 responden $(63,6 \%)$.

3. Warung makan di Terminal Purabaya yang telah melaksanakan 10 indikator PHBS ( klasifikasi IV ) sebesar 16,4\%, sedangkan $83,6 \%$ atau 46 warung makan baru melaksanakan $7-9$ indikator. Hal ini disebabkan tingkat pengetahuan dan sikap terdapat PHBS masih kurang.

4. Dari hasil wawancara di Terminal Purabaya belum pernah dilakukan PHBS kepada pedagang dan pemilik warung makan, dari hasil observasi diketahui bahwa tidak ada media terkait program PHBS di terminal.

\section{SARAN}

1. Bagi Dinas Perhubungan dan Dinas Kesehatan Kota Surabaya agar mempromosikan tentang PHBS tatanan tempat - tempat umum karena selama ini para pedagang dan pemilik warung makan belum pernah tahu tentang PHBS

2. Bagi pengelola Terminal Purabaya untuk lebih memperhatikan fasilitas dan sarana penunjang serta melakukan sosialisasi lewat media massa berupa poster, spanduk, liflet, dan lain - lain guna meningkatkan tingkat pengetahuan, sikap, dan tindakan atau perilaku pemilik warung makan terkait PHBS.

3. Bagi pemilik warung makan yang masih belum memenuhi syarat PHBS diharapkan meningkatkan kualitas warung makannya. Dan bagi yang sudah memenuhi syarat PHBS untuk tetap menjaga agar tidak menurun kualitas warung makan yang bersih dan sehat

\section{DAFTAR PUSTAKA}

Chandar, budiman, 2006. Pengantar kesehatan lingkungan. Jakarta, penerbitbuku kedokteran EGC: 175 - 185

Departemen Kesehatan RI Pusat Promosi Kesehatan, 2007. Rumah tanggasehat dengan perilaku hidup bersih dan sehat. Jakarta Selatan: 20 - 34

Dinas Kesehatan Provinsi Jawa Timur, 2001. Buku saku pelaksanaan perilakuhidup bersih dan sehat ( PHBS ). surabaya 
Lukluk A., Zuyina, siti bandiyah, 2011. Psikologi kesehatan. Yogyakarta, Nuhamedika. Cetakan I: 25 - 42

Maryunani, Anik, 2012. Perilaku hidup bersih dan sehat ( PHBS ). Jakarta, Cv.Trans info media. Edisi pertama: $201-212$

Meidina.2012. Hubungan Antara Pendidikan, Pendapatan, Pengetahuan Dan Sikap Dengan Praktik Perilaku Hidup Bensih Dan Sehat (Phbs) Pada Pedagang Makanan Di Pasar Swering Kota

Ternate.http://webcache.googleusercontent.com isearch?q $=$ cache: $153134 \mathrm{Kp}$ UkJ:pascasarjanaunsrat.com/home/wpcontent/uploads/2012/08/HUBUNGANANTARA-PENDIDIKAN-PENDAPATANPENGETAHUAN-DAN-SIKAP-DENGANPRAKTIK- PERILAKU-HIDUP-BERSIHDAN-SEHAT-PHBS-PADA-PEDAGANGMAKANAN-DI-PASAR-SWERINGKOTATER.doc $+\& \mathrm{~cd}=1 \& \mathrm{kh}=\mathrm{id} \& \mathrm{ct}=\mathrm{clnk} \& \mathrm{~g}$ l=id. 27 Juni 2014

Mukono, H.J, 2000. Prinsip dasar kesehatan lingkungan. Surabaya, airlanggauniversity press: $135-140$
Notoatmodjo, Soekidjo, 1997. I/mu kesehatan masyarakat. Jakarta, PT. Rinekacipta. Edisi pertama: $118-145$.

Notoatmodjo, Soekidjo, 2010. IImu perilaku kesehatan. Jakarta, PT. Rineka cipta.Edisi pertama: $20-147$

Notoatmodjo, Soekidjo, 2012. Metodologi penelitian kesehatan. Jakarta, PT.Rineka cipta. Edisi kedua: $24-186$

Permenkes RI

Nomor 2269/MENKES/PER/XI/2011 Tentang Pedoman Pembinaan Perilaku Hidup Bersih dan Sehat (PHBS).

Suparlan, 2012. Pengantar pengawasan hygine sanitasi tempat - tempat umum-wisata \& usaha - usaha untuk umum. Surabaya, percetakan dua tujuh. Cetakan 3: 3 - 25

Undang - Undang no. 23 Tahun 1992 tentang Kesehatan

Yuliantini, herlia, 2011. Tingkat pengetahuan HIV/AIDS dan sikap remajaterhadap perilaku seksual pranikah di SMA " $X$ " di jakarta timur,. Sripsi,fakultas Ilmu Keperawata Universitas Indonesia Depok: $14-18$ 